\section{The relationship between job stress and organizational commitment of the employees working in the tourism busineses; the case of Çeşme and Kartepe}

\section{Turizm işletmelerinde} çalışanların yaşadıkları iş stresi ile örgütsel bağlılıkları ilişkisi, Çeşme ve Kartepe Örneği

\author{
Adalet Nükhet Akpulat ${ }^{1}$ \\ Tülay Polat Üzümcü ${ }^{2}$ \\ Esin Karacan ${ }^{3}$
}

\begin{abstract}
The present study was conducted in order to examine job stress and organizational commitment of employees in tourism establishments (hotel, restaurant, travel agency, etc.) in Çeşme and Kartepe destinations which have different touristic attractions. The study survey was administered to a total of 351 employees working at tourism establishments in Çeşme, a summer tourism destination in the province of Izmir and Kartepe, a winter tourism destination in the province of Kocaeli. The data obtained as a result of the study were analyzed with computer software for the purpose of the study. Frequency and percentage distributions were examined in order to reveal demographic characteristics and t-test and pearson correlation analysis were used to test hypotheses. No significant difference in terms of job stress was found between employees working at tourism establishments in Çeşme and Kartepe depending on their destination. A significant difference was observed in the organizational commitment scale between employees depending on their destination. According to this result, comparing answers given to the organizational commitment scale according to
\end{abstract}

\section{Özet}

Bu çalışma, farklı turistik çekiciliklere sahip olan Çeşme ve Kartepe destinasyonlarında çalışan turizm işletmeleri personelinin, iş stresleri ve örgütsel bağlllıkları ilişkisinin incelenmesi amacıyla yapılmıştır. Araştırma anketi, İzmir ili Çeşme yaz turizmi destinasyonu ve KocaeliKartepe kış turizmi destinasyonunda yer alan turizm işletmelerinde çalişan toplam 351 personele uygulanmıştır. Araşturma sonucunda elde edilen veriler araştırma amacı kapsamında bilgisayar programı ile analiz edilmiştir. Çalışmada demografik özellikleri ortaya çıkarmak amacı ile frekans ve yüzde dağılımları incelenmiş, hipotezleri test etmek amaciyla t-testi ve pearson korelasyon analizi kullanılmıştur. Çeşme ve Kartepe'de çalışan turizm işletmeleri personeli, çalıştıkları destinasyonlara göre değerlendirildiğinde, iş stresi ölçeğinde anlamlı farklılaşmanın olmadığ görülmüştür. Personel çalıştıkları yere göre değerlendirildiğinde ise, örgütsel bağlllık ölçeğinde anlamlı bir farklılaşmanın olduğu görülmüştür. Örgütsel bağlllık ölçeğine verilen cevapları Çeşme (yaz turizmi), Kartepe (kış turizmi) ayrımına göre karşılaştırdığımızda, Çeşme destinasyonunda çalışan personelin örgütsel bağlıllı̆ının daha

\footnotetext{
1Ph.D., Ege University, Çeşme Tourism and Vocational Highschool, nakpulat@yahoo.com

2 Assist. Prof. Dr., Kocaeli University, Kartepe Tourism Vocational School, tulay.uzumcu@kocaeli.edu.tr

${ }^{3}$ Assoc. Prof. Dr., Kocaeli University, Vocational School of Justice,ekaracan@,kocaeli.edu.tr
} 
Akpulat, A. N., Polat Üzümcü, T., \& Karacan, E. (2016). Turizm işletmelerinde çalıșanların yaşadıkları iş stresi ile örgütsel bağlllıkları ilişkisi, Çeşme ve Kartepe Örneği. Journal of Human Sciences, 13(3), 5136-5149. doi:10.14687/jhs.v13i3.4192

the distinction of Ceșme and Kartepe, it was found that employees working in Çeşme had higher organizational commitment. A weak, negative and significant correlation was observed between job stress and organizational commitment of employees working at tourism establishment.

Keywords: Tourism employees; job stress; organizational commitment; tourism establishments; destination.

(Extended English abstract is at the end of this document) yüksek olduğu anlaşılmaktadır. Turizm işletmeleri personelinin iş stresi ile örgütsel bağllliğ1 arasında ise, düşük düzeyde negatif ve anlamlı bir ilişki olduğu görülmüştür.

\section{GİRİŞ}

Günümüzde hizmet sektörünün en önemli kollarından birisi olan turizm sektörü, müşteri memnuniyeti odaklı olup, çalışanlar çoğu sektörden daha farklı ve yoğun bir gayret göstermektedirler. Turizm sektörünün yapısı gereği, uzun çalışma saatleri, güler yüzlü hizmet ve değişen müşteri beklentileri, çalışanlar üzerinde baskı oluşturmaktadır. Turizm işletmelerinde işin mevsimlik oluşu ve düşük ücret politikaları, çalışanların iş ve aile yaşamını olumsuz etkilemektedir. $\mathrm{Bu}$ durum, işletmelerde kalifiye personel sıkıntısı yaratmakta ve işgücü devir hızını artırmaktadır. Turizm işletmeleri ve çalşsanları üzerinde oluşan bu baskı ise, önemli oranda iş stresine neden olabilmektedir (Turunç, 2015).

Örgütlerde çalışanlarının büyük bir kısmını etkileyen iş stresi, çalışan verimliliği üzerinde belirli bir oranda olumlu etki yaratmasına karşın, o oranın üstünde istenmedik rahatsızlık verici durumlara ve tutumlara yol açabilmektedir (Ironson, 1992:35; aktaran: Turunç, 2015). Örgütlerde stres bazı çalışanları olumsuz etkilerken, bazılarının performanslarını artıran olumlu bir güç haline gelebilmektedir. İş ortamında stres yükü fazla olan bir çalışanın bulunması, hem kişinin kendisini, hem de diğer çalışanların güvenliğini olumsuz yönde etkileyebilmektedir (Genç, 2005:263). Hem bireysel hem de örgütsel pek çok faktörün öncülü ve kimi zaman ardılı olan iş stresi, sonuçları itibari ile yönetilmesi gereken önemli bir faktördür.

Bireysel ve örgütsel kaynaklı stres, çalışanlara ve örgüte büyük zararlar vermektedir. Bu noktada, çalışanların stres ve stresle başa çıkması hususunda, örgütlerin stresin olumsuz etkilerini azaltma ve stresi kontrol altına alma noktasında bilinçlenmeleri önem taşımaktadır (Çınar, 2010: 102). İş yükünün fazla olması, çalışanın rolünün belirsizliği, kariyer beklentisinin karşılanmaması, ücret yetersizliği, çalışma şartlarının kötü olması, çalışma arkadaşlarıyla çözümlenemeyen problemler, çalışanın stresini arttırarak işe konsantrasyonunu ve işini sevmesini zorlaştıracak ve işletme amaçlarına ulaşmak için gerekli olan motivasyonu düşürecektir (Aslan ve Cengiz, 2015: 36). $\mathrm{Bu}$ etkileri nedeniyle örgütlerde; stresin kaynakları, stres yapıcıların neler olduğu, kişiyi ne gibi psikolojik veya fizyolojik rahatsızlıklara sürüklediği, stresle baş etmek için kişinin, sosyal çevrenin ve örgütün ne tür önlemler alıp uygulayacağı konuları önemli hale gelmiştir (Sabuncuoğlu ve Tüz, 2003: 231).

İsyerinde yaşanan yüksek seviyedeki stres nedeniyle ortaya çıkan olumsuzlukların çalışanların örgütlerine olan bağlılık duygularını etkileyebileceği düşünülmektedir (Çelik ve Turunç, 2009). Bu sebeple son yıllarda örgütsel bağlllık, örgütlerin çalışan sorunlarının çözümünde önemle üzerinde durdukları konulardan biri haline gelmiştir. Örgütsel bağlllık, bireylerin örgüte karşı hissettikleri psikolojik bağlllıktır. Bağllık, ise duyulan ilgi, sadakat ve örgüt değerlerine karşı duyulan güçlü 
Akpulat, A. N., Polat Üzümcü, T., \& Karacan, E. (2016). Turizm işletmelerinde çalıșanların yaşadıkları iş stresi ile örgütsel bağlllıkları ilişkisi, Çeşme ve Kartepe Örneği. Journal of Human Sciences, 13(3), 5136-5149. doi:10.14687/jhs.v13i3.4192

inançtan kaynaklanmaktadır (O'Reilley, 1989; aktaran: Candan ve Çekmecelioğlu, 2009:46). Örgütsel bağlılık ile ilgili yapılan araştırmaların sonuçları incelendiğinde, düşük işgücü devri, düşük devamsızlık, düşük geç gelme oranı ve artan iş performansı ile pozitif bir ilişkisi içerisinde olduğu görülmüştür (Mathieu ve Zajac, 1990; Meyer et al., 2001; Atlas ve Gündüz Cekmecelioğlu, 2007; aktaran: Candan ve Çekmecelioğlu, 2009:46).

Örgütsel bağlllık, çalışan ve yöneticilerin örgütün değerlerine sadık kalma eylemidir. Böylelikle bireyler, hem kendilerinin hem de örgütün prensip ve değerlerine uyum sağlamış olacaklardır. Clayton'a göre örgütsel bağlllık, çalışanın örgütün amaç ve hedeflerini benimsemesi, örgütün çıkarlarını kişisel çıkarlarının üstünde tutması ve örgüt üyeliğini gönüllü olarak sürdürmesidir (Clayton, 2000:160; aktaran: Demirel, 2009: 116). Örgütsel amaçlara bağlllık, sadece belli bir rolün başarı derecesini nitelik ve nicelik yönünden yükselterek, işe devamsızlığın ve issgücü devrinin azalmasına katkı sağlamakla kalmaz, aynı zamanda bireyi, örgütsel yaşam ve sistem başarısı için gerekli birçok gönüllü eyleme yöneltir (Katz ve Kahn 1977,436; aktaran: Balay, 2000, 3-4).

$\mathrm{Bu}$ araştırma da, farklı turistik çekiciliklere sahip olan Çeşme ve Kartepe turizm destinasyonlarında çalışan turizm işletmeleri personelinin (otel, restoran, seyahat acentası vb.) iş stres düzeyleri ile örgütsel bağlılıkları ilişkisi irdelenmiştir. Araştırma anketleri, İzmir ili Çeşme turizm destinasyonu ve Kocaeli ili Kartepe turizm destinasyonunda uygulanmış olup, Çeşme turizm işletmelerinde çalışan 155 personel ile Kartepe turizm işletmelerinde çalışan 139 personel tarafindan yanıtlanmıştır. Araştırmanın anketinde, iş stresi ve örgütsel bağlılık ile ilgili sorularda, İş Stresi Ölçeği (House ve Rizzo, 1972) ve Örgütsel Bağlılık Ölçeği (Huselid ve Day, 1991) kullanılmıştır. Araşturma sonucunda elde edilen veriler araştırma amacı kapsamında bilgisayar programı ile analiz edilmiş, demografik özellikleri ortaya çıkarmak amacı ile frekans ve yüzde dağıllımları incelenmiş, hipotezleri test etmek için de t-testi ve pearson korelasyon analizi yapılmıştır. Araştırma sonucunda Çeşme ve Kartepe'de çalışan turizm personeli, çalıştı̆̆1 destinasyona göre değerlendirildiğinde, iş stresi ölçeğinde anlamlı farklılaşmanın olmadığı görülmektedir. Örgütsel bağlllık ölçeğine verilen cevapları, Çeşme destinasyonu (yaz turizmi)- Kartepe destinasyonu (kış turizmi) ayrımına göre karşılaştırdığımızda ise, Çeşme ilçesinde çalışan personelin örgütsel bağlllğının Kartepe ilçesi çalışanlarından daha yüksek olduğu anlaşılmaktadır.

\section{LİTERATÜR İNCELEMESİ}

Stres belli bir eşik noktaya kadar verimliliği yükseltmekte, belli bir aşamadan sonra ise y1kıc1 ve performans düşürücü etkileri olabilmektedir. Issten kaynaklanan yüksek seviyedeki stres nedeniyle ortaya çıan olumsuzlukların iş görenlerin örgütlerine bağll1ık duygulannı da etkileyebileceği düşünülmektedir (Çelik ve Turunç, 2009: 218). Bu bağlamda, bu bölümde araştırmanın konusu olan iş stresi ve örgütsel bağlllık ile ilgili kavramsal bilgi verilecektir.

\section{1 İş Stresi}

Latince "estricta" kökünden gelen stres kelimesi Fransizcada "estrece" kelimesiyle ifade edilmektedir. 17. yüzyılda kavram, felaket, belâ, sıkıntı, elem, keder anlamlarında kullanılırken 18. ve 19. yüzyılda kavram, öznelere veya nesnelere yönelik uygulanan bir güç, baskı veya basıncı ifade etmek için kullanılmaktadır. Daha sonra bütün bu temellerle stres, dış güçlerin etkisiyle, objelerin biçimlerindeki değişikliği, bozulma veya direnç şeklinde tanımlanmıştır (Webster's Encylopedic Unbridged Dictionary, aktaran: Aslan ve Cengiz, 2015: 27).

İlk kez stres sözcügünü 17. yüzyllda fizikçi Robert Hook, 1914 yllinda ise Walter Cannon ele almıştır. Cannon duygusal tepkilerin hastalıklara yol açabilecek fiziksel değişimlerle ilgisini incelemiştir. Stres konusunda bir otorite olan Hans Selye ise, Cannon'u haklı bularak stresi, bireyi etkileyen çevresel uyarıcı olarak görmüştür. Ancak Selye, yaptığı çalışmalar sonucunda 1936 yılında (Aydın, 2004:51) stresi, "herhangi bir talebe, vücudun verdiği özel olmayan tepki" olarak tanımlanmıştır(Selye,1976: 53). Shermerborn ve arkadaşlarına (1988) göre stres, olağanüstü talepler, 
Akpulat, A. N., Polat Üzümcü, T., \& Karacan, E. (2016). Turizm işletmelerinde çalıșanların yaşadıkları iş stresi ile örgütsel bağlllıkları ilişkisi, Çeşme ve Kartepe Örneği. Journal of Human Sciences, 13(3), 5136-5149. doi:10.14687/jhs.v13i3.4192

baskılar veya firsatlardan dolayı bireyde oluşan gerilim durumudur (Spence vd. 1999; Roohafza vd. 2012; aktaran: Turunç, 2015:147). Davis (1982:83) ise stresi "bir kişinin duygularında, düşünce süreçlerinde veya fiziki şartlarında, kişinin çevresi ile baş edebilme gücünü tehdit eden bir gerilim durumu" olarak tanımlanmaktadır. Magnuson (1990)'a göre stres, kişinin gerçek dünyası ile beklentileri arasındaki farklıllğa gösterdiği tepkidir. Lazarus (1985:1421) ise stresin başlama sınırını kişinin dayanma gücü olarak ifade etmekte ve stresi "kişiden kaynaklanan bireysel dayanma gücünü aşan, bireye göre kendisini tehdit eden ilişkilerin toplamı" olarak tanımlamaktadır (Turunç, 2015:147). Eren de stresi, "bireyin içinde bulunduğu ortam ve iş koşullarının onu etkilemesi sonucunda vücudunda özel biyo-kimyasal salgıların oluşarak söz konusu koşullara uyum için düşünsel ve bedensel olarak harekete geçmesi durumu" olarak tanımlamıştır (Eren, 2004:292).

Yetmişli yıllarda yapılan bazı basit deneyler "çeşitli ajanlar tarafindan önerilen bir sendrom" başlıklı bir yazının "Nature"da yayınlanmasını sağladı. O zamandan beri "stress kavramı" bilinen farklı yönleriyle, sadece tıp alanında değil aynı zamanda felsefe ve davranıs bilimlerinde 110.000'den fazla defa yayınlanmıştır. Bir ansiklopedi, 7518 anahtar referansı listeleyerek "Yaşamın Stresi"nin güncellenmiş sürümünü özetlemiştir (Selye,1976: 53).

Bir stresör, herhangi bir zamanda stres üreten bir ajandır. Genel adaptasyon sendromu, stresörlerin eylemlerinin gelişimini gösteren süreçtir. Bu süreç üç aşamadan oluşmaktadır: Alarm reaksiyonu, direnç aşaması ve tükenme aşamasıdır (Selye, 1976: 53)."Stresi ortadan kaldırmak" için çeşitli ilaçların (sakinleştiriciler, vitaminler ve hatta uyuşturucu maddeler) kullanımının önerilmesi pek çok karışıklığa sebep olmuştur. Bu ilaçların bir kısmı duygusal çöküntüyü azaltırken bir kısmı hiçbir etki yapmadığı gibi zararlı bile olabilmektedir (Selye,1976: 56).

Stres, insan bedeninde yer alan bir süreç olmakla beraber aynı zamanda, insan bedeninin çevresinden gelen zorlayıcılara uyum sağlamasının da olağan bir sonucudur (Güney, 2011:407). Stres, birey ile stres yaratan nedenler arasındaki etkileşim sonucu meydana geldiğinden, stres nedenlerinin bireyden, çevresinden ve çevre ilişkilerinden kaynaklandığı düşünülmektedir (Keskin, 1997; aktaran: Aydın, 2004: 54). Bu sebeple, stres nedenleri; bireysel ve çevresel olarak gruplandırılmakta ancak bireyi iş yaşantısı dışında değerlendirmek mümkün olmayacağından üçüncü bir neden olarak iş stresini de eklemek yerinde olacaktır (Aydın, 2004:54; Balc1, 2002:79).

İş stresi literatürde, çevresel talep durumunda, talebi karşılamak için başarının önemli olduğu algılandığında, talep ile karşı tepki yeteneği arasındaki fark olarak açıklanmaktadır (Millson, 2007; aktaran: Aslan ve Cengiz, 2015: 27). Lazarus (1991), iş stresinin nedenini çalışan ve çevresi arasındaki uyumsuzluk olarak açıklayan yaklaşımı, çalışan-çevre ilişkisinin durağan değil değişken olduğunu belirterek eleştirmekte, Schuler (1980) ise, çalş̧an-çevre ilişkisinde denge durumunun yani çalışanın iş stresi yaşamadığı durumun hiçbir zaman var olmayacağını belirtmektedir. Bazı araştırmacılar da, çalışan tarafindan algılanan iş stresi kaynaklarının ya da işte çalışmanın algılanan sonuçlarının sadece iş çevresiyle ilgili olup olmadığını sorgulamaktadır (Spector, 1992; aktaran: Efeoğlu ve Özgen,2007: 239).

İş ortamında stres; çalışanların verimlerinin düşmesine, işten ayrılma ve işe devamsızlık oranlarının artmasına, kazalara, yaralanmalara, çeşitli hastalıkların ortaya çıkmasına neden olmakta, sigara, alkol, ilaç kullanımını tetiklemekte, yöneticilerin etkin karar vermelerini engellemektedir. $\mathrm{Bu}$ sebeple, stresin sadece bireyin kendisini ilgilendiren bir sağlık sorunu olmayıp, esasında örgütün işleyişini bozan bir faktör olduğu da görülmektedir (Çınar, 2010: 102).

İş stresi, stresin işten kaynaklanan yönü olarak günümüz çalışanlarının neredeyse tümünde belirli seviyede rastlanılan önemli bir olgudur. İş stresi, belirli bir ölçekte, çalışan verimliliği üzerinde olumlu etkisi olan bir faktör olmasına karşın, o seviyenin üstünde çalışanlarda istenmedik rahatsızlık ve tutuma yol açan önemli bir sorundur (Ironson, 1992:35; aktaran: Turunç, 2015). İş stresörleri çeşitli şekillerde ortaya çıkar. İşyerindeki herhangi bir şey çalışan için stres kaynağı olabilir (Özkalp ve Kırel, 336). Stres bazı kişilere olumsuz etki ederken, bazıları için performanslarını artıran yapıcı bir güç haline gelebilmektedir. Bu açıdan stres; yapıcı stres (eustress) ve yıkıcı stres (distress) olmak üzere ikiye ayrılmaktadır. Yapıcı stres yaşandıkça neşe, canlılık, istek yaratan bir durumdur ve 
Akpulat, A. N., Polat Üzümcü, T., \& Karacan, E. (2016). Turizm işletmelerinde çalıșanların yaşadıkları iş stresi ile örgütsel bağlllıkları ilişkisi, Çeşme ve Kartepe Örneği. Journal of Human Sciences, 13(3), 5136-5149. doi:10.14687/jhs.v13i3.4192

faydalıdır. Özellikle iş ortamında bireyin becerisine ve iş görme gücüne yardımcı olan bir coşku, bir enerji şeklinde ortaya çıan bu tür stres, yaşama renk katarak güdüleyici olabilmektedir. Örneğin seyirci karsısında rakipleriyle yarışan bir atlet, stres sayesinde daha üst düzeyde performans sergileyerek rekor kırabilmektedir. Yine terfi etmek, başarmak gibi arzulanan olaylar yapıcı strese örnek olarak verilebilir. Yıkıcı stres ise kişide kaygı veya depresyonla sonuçlanabilecek zararlı bir durumdur. Ölüm, işsiz kalmak, iş gereklerine yeterince uyamamak, rol özelliklerini yerine getirememek, meslekte gereken ilerlemeyi sağlayamamak ve iletişim engelleri gibi durumlar olumsuz strese örnektir (Bingöl, 1996:420; Chaplin, 2001:197-215; Rowshan, 2002:12; Erkek, 2008:13; Simsek vd., 2008:329; aktaran: Çınar, 2010: 104-105).

Hem bireysel hem de örgütsel pek çok faktörün öncülü ve kimi zaman ardilı olan iş stresi, sonuçları itibari ile yönetilmesi gereken önemli bir faktördür. Çalışma ortamında stres yükü fazla olan bir çalışanın bulunması, hem kişinin kendisini hem de diğer çalışanların güvenliğini olumsuz yönde etkiler (Genç, 2005:263).İs stresinin çalışanlar üzerinde; endişe, kayg1, konsantrasyon kayb1, uyuşturucu ve alkol kullanımı gibi etkileri olurken (Ironson, 1992:35; aktaran: Turunç, 2015), işletmelerde de; işe devamsızlık, performans düşüklügü, verimliliğin azalması, sağlık sigortaları ödemelerinin artması, personel devir hızındaki artıs, hırsızlık ve sabotaj gibi olumsuz etkileri olabilmektedir (Büyükbeşe, 2004; Sabuncuoğlu ve Tüz, 1996; aktaran: Turunç, 2015:146).

\section{2 Örgütsel Bağlılık}

Örgütsel bağlllık konusu, birçok disiplinin çalışma alanına girmekte ve bu nedenle her disiplinin kendine özgü farklı tanımlarının olduğu görülmektedir (Korkmaz ve Erdoğan, 2014; Gündoğan, 2009). Schermerhorn vd. göre (1994), örgütsel bağlllık çalışanın örgüt ile kurduğu kuvvet birliğinin ve kendisini örgütün bir parçası olarak hissetmesinin derecesidir. Sheldon'a göre (1971) kişinin kimliğini örgüte bağlayan tutum veya eğilimlerdir. Wiener (1982) ise örgütsel bağl1lı̆̆1, örgütsel çıkarlara yönelik hareket etmek için içselleştirilmiş normatif baskıların bir toplamı olarak ifade ederken (Gündoğan, 2009: 4).Mowday vd., (1979) örgütsel bağlllı̆̆1, belirli bir örgütle bireysel olarak kendini özleştirme derecesi ve örgüte karşı olan ilgisi olarak tanımlamaktadır. O'Reilley ve Chatman (1986) örgütsel bağlllı̆̆1, bireyin örgüte karşı hissettiği psikolojik bağlllık olarak ifade etmekte, Allen ve Meyer (1990) ise örgütsel bağlllı̆̆ bireyi örgüte bağlayan psikolojik bir durum olarak açıklamaktadır (Korkmaz ve Erdoğan, 20154: 545).

Örgütsel bağlllık, çalışanların örgüte olan psikolojik bağllliklarını ifade etmektedir. İş sonuçları, iş tatmini, isteklendirme ve performans düzeyinin beklentilerin üzerinde gerçekleşmesi durumunda bağlllıktan söz edilebilir (Chen ve C.Chen, 2008:282; aktaran: Demirel, 2009: 116). Örgütsel bağllık, çalışanların işe yönelik tutum ve davranışlan ile ilgili bir kavramdır ve çalışanın işe olan sadakati, iş ile özdeşleşmesi ve işe olan uyumudur. Örgütsel değer ve inançlar ile bireysel değer ve inançlar arasındaki uyum düzeyi ne kadar yüksek olursa, örgüte olan bağllilk duygusu da o oranda yüksek olmaktadır. Örgütsel bağlllığın yüksek olduğu örgütlerde iş performans1, iş tatmini, bilgi paylaşımı, örgütsel güven, işe devam, kaynakların etkin kullanımı vb. konuların oranı da yüksek olmaktadır (Demirel, 2009: 116).

Mowday ve arkadaşları (1979), örgütsel bağlılığı anlayabilmek için hem çalışanları hem de örgütsel uygulamaları incelemek gerektiğini belirtirken, Aronson (1999), örgütsel bağllliğı uyum, Özdeşleşme ve içselleştirmeden oluşan bir süreç olarak kabul etmiştir (Mowday vd. 1979, 224; Aronson, 1999, 179; aktaran: Gündüz ve Güzel, 2014: 3). Uyum süreci, çalışanların ödül elde etmek veya cezadan kaçmak için sergilediği tutum ve davranışları, özdeşleşme süreci çalışanların diğer çalışma arkadaşlarıyla ilişkilerini korumak amacıyla onların etkisini kabul etmesi ve onlara benzeme isteği; içselleştirme ise; çalışanların örgütün değerleri ile kişisel değerleri arasında uyum hissetmesidir (O'Reilly, 1989, 17; aktaran: Gündüz ve Güzel, 2014: 3).

Meyer ve Allen (1984), başlangıçta örgütsel bağllılıla ilgili yapılan çalışmalara dayanarak, örgütsel bağlllı̆̆ın; duygusal bağlll1k ve devamlılık bağlllı̆̆ olmak üzere iki boyutlu olarak kavramsallaştırılmasını önermişlerdir. Ancak, daha sonra Meyer ve Allen (1990) örgütsel bağlllığa, 
Akpulat, A. N., Polat Üzümcü, T., \& Karacan, E. (2016). Turizm işletmelerinde çalıșanların yaşadıkları iş stresi ile örgütsel bağlllıkları ilişkisi, Çeşme ve Kartepe Örneği. Journal of Human Sciences, 13(3), 5136-5149. doi:10.14687/jhs.v13i3.4192

normatif bağlliık olarak adlandırılan üçüncü bir kavramı eklemişlerdir. Normatif bağlllık kavramına göre çalışanlar kendilerini örgüte karşı yükümlü ve sorumlu hissetmektedirler (Meyer ve Allen, 1990:2).

Şekil 1: Üç Bileşenli Örgütsel Bağlllık Modeli (Meyer vd., 2002:22)

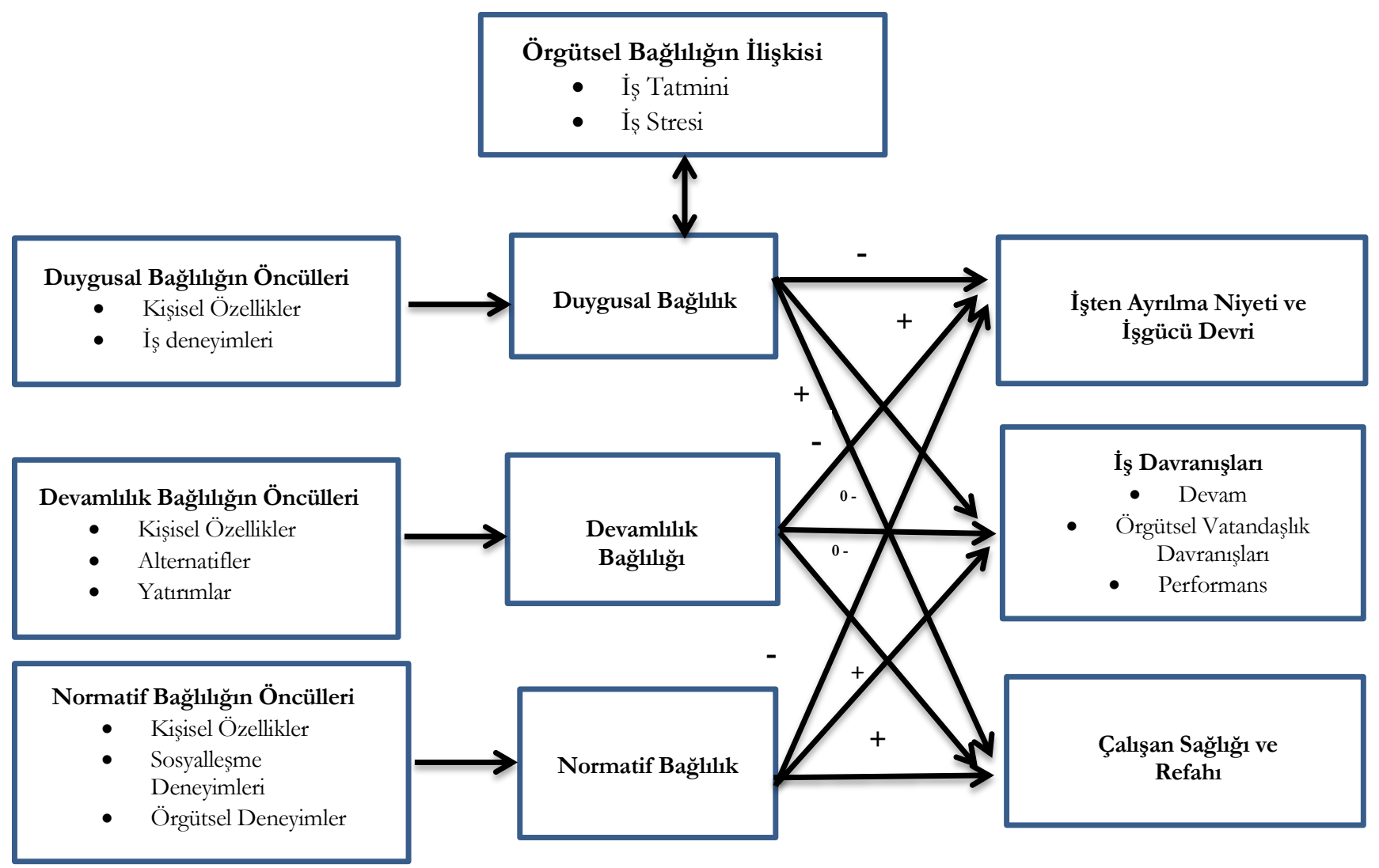

Şekil 1'de, örgütsel bağlllĕğn üç bileşeni ve değişkenleri göz önünde bulundurularak, kendi öncülleri, ilisskileri ve sonuçları arasındaki bağların bir özeti gösterilmektedir. Şekill’in sol tarafinda, Meyer vd. (2002), duygusal, devamlılık ve normatif bağlılı̆̆ın gelişmesinde katkıda bulundukları öne sürülen değişkenlerin, genel kategorilerini belirlemişlerdir. Şeklin să̆ tarafinda ise, bağlllı̆̆ın sonuçları olarak kabul edilen değişkenler yer almıştır. Üç bileşenli modelin geliştirilmesi için rasyonelliğin önemli olduğuna inanılırdı ki, bağlllı̆̆ı üç formu da işgücü devri ile olumsuz ilişkili olmasına rağmen, onlar diğer işle ilgili davranışların farklı bir şekilde ölçülmesiyle ilişkilidir (örneğin, katıllım, rol performansı, örgütsel vatandaşlık davranışı). Daha spesifik olarak, duygusal bağllliğın en güçlü pozitif ilişkiye sahip olması beklenir, onu normatif bağlllık izler, devamlılık bağlllı̆̆nın ise, bu istenen iş davranışlarıyla ilişkisiz ya da olumsuz ilişkili olacağı beklenmektedir (Meyer vd., 2002: 21). Duygusal bağlllık, bireyin örgütle güçlü bir bağ kurarak kendisini tanımlamasını, örgütün içinde olmaktan ve örgütün bir üyesi olmaktan mutluluk duymasını, devam bağlllı̆ı bireyin örgütten ayrrlmasının neden olacağı maliyetlerin farkında olmasını, normatif bağllık ise bireyin örgütte çalışmaya devam etme durumunu bir sorumluluk olarak görmesini ifade etmektedir (Meyer ve Allen, 1987: 200; aktaran: Korkmaz ve Erdoğan, 2014: 545).

Yakın zamana kadar, örgütsel bağlllık teorisi ve araştırmalar, öncelikle işverenlerle ilgili sonuçlar üzerinde odaklanmıştır. Son zamanlarda araştırmaların büyük çoğunluğu, stres ve iş-aile çatışması sonuçları içeren, çalışanlarla ve bağlılık arasındaki sonuçları incelemektedir. Bu nedenle modelin sonuç kategorisine, çalışan sağlığı ve refahını dahil etmişlerdir (Meyer vd., 2002: 22). Çok 
Akpulat, A. N., Polat Üzümcü, T., \& Karacan, E. (2016). Turizm işletmelerinde çalıșanların yaşadıkları iş stresi ile örgütsel bağlllıkları ilişkisi, Çeşme ve Kartepe Örneği. Journal of Human Sciences, 13(3), 5136-5149. doi:10.14687/jhs.v13i3.4192

boyutlu olan bu örgütsel bağlllk modeli oldukça kabul gören ve kullanılan bir model olarak bilinmektedir (Altaş ve Çekmecelioğlu,2015: 426).

Örgütsel bağlllık üzerine yapılan çalışmalar konunun işletmeler üzerindeki etkisinin ne kadar önemli olduğunu ortaya koymaktadır (Bayram, 2005; Duygulu ve Abaan, 2007; Bolat ve Bolat, 2008; Gül vd., 2008; aktaran: Kavacık, Baltac1 ve Yıldız, 2013: 76). Örgütsel bağlllı̆̆1 yüksek olan çalışanların gelecekle ilgili endişeleri ve işten ayrılma niyetleri oldukça düşük seviyelerde olmakta, örgütün amaç ve hedeflerini içselleştirdiklerinden iş stresleri ve iş yavaşlatma eylemleri de düşük seviyelerde kalmaktadır (Wasti, 2005: 296; aktaran: Kavacık, Baltacı ve Yildız, 2013: 76).

\section{METODOLOJİ}

$\mathrm{Bu}$ araştırmada, anket aracından faydalanılarak, İzmir ili Çeşme yaz turizmi destinasyonu ve Kocaeli ili Kartepe kış turizmi destinasyonlarında yer alan turizm işletmeleri çalışanlarının iş stresleri ve örgütsel bağlılıkları ilişkisi incelenmeye çalışılmıştır. Anketin kullanılma sebebi, nispeten geniş bir örneklem üzerinde kolay veri toplamayı olanaklı kilması ve istatistiksel programlarla elde edilen verilerin rahatıkla analiz edilebilir olmasıdır.

\section{1. Evren ve Örneklem}

Araştırmanın temel konusu, Çeşme ve Kartepe turizm destinasyonlarında çalışan turizm işletmeleri personelinin, iş stresleri ve örgütsel bağlllıkları ilisskisinin incelenmesidir. Bu nedenle araştırmanın evreni Kartepe ve Çeşme ilçelerinde turizm işletmelerinde çalışanlardır. Araştırma örnekleminin Çeşme ve Kartepe ilçeleri seçilmesi, yaz destinasyonu olan çeşme ile Kış destinasyonu olan Kartepe ilişkisini ortaya koymaktır. Araştırma da olasıllklı olmayan örnekleme tekniklerinden kolayda örnekleme uygulanmıştır. "Bu örnekleme yöntemi araştırmacıya hız ve pratiklik kazandırır. Çünkü bu yöntemde araştırmacı, yakın olan ve erişilmesi kolay olan bir durumu seçer" (Yıldırım ve Şimşek, 2004). Bu sebeple araştırmacıların akademik çalışma alanları olan Kartepe ve Çeşme turizm destinasyonları tercih edilmiştir.

Araştırma anketleri; 185 Çeşme ve 139 Kartepe destinasyonu olmak üzere, toplamda 351 turizm çalışanına uygulanmış, 324 anket değerlendirilmiş, 22 anket ise eksik cevaplama ve tüm cevaplarda aynı şıkkı işaretleme gibi nedenlerden dolayı değerlendirme dışında bırakılmıştır.

\subsection{Araştırmanın Amacı}

$\mathrm{Bu}$ araştırmada, kış turizminde çalsşan turizm personeli ile yaz turizminde çalışan turizm personelinin iş stresleri ve örgütsel bağllıkları ilişkisinin incelenmesi amaçlanmaktadır.

\subsection{Araştırma Hipotezleri}

H1 ve H2'de k1ş turizmi destinasyonu olan Kartepe ile yaz turizmi destinasyonu olan Çeşme'de çalışan personelin iş stresleri ve örgütsel bağlılıkları arasında anlamlı bir farklılık olup olmadığ1 incelenmektedir. H3'de ise turizm çalışanlarının iş stresleri ve örgütsel bağlllıkları arasında ilişki olup olmadığına bakılmaktadır.

$\mathrm{H} 1=$ Turizm çalışanlarının çalıştıkları destinasyona göre (Çeşme ve Kartepe) iş stresleri açısından anlamlı bir farklılık vardır.

H2=Turizm çalışanlarının çalıştıkları destinasyona göre (Çeşme ve Kartepe) örgütsel bağlllıkları açısından anlamlı bir farklılık vardır.

H3=Turizm çalışanlarının iş stresi ve örgütsel bağlılıkları arasında anlamlı bir ilişki vardır.

\subsection{Araştırmanın Ölçekleri}

Çalışanların iş stresinin örgütsel bağlılıkları üzerindeki etkisini belirlemek amacı ile yapılan bu araştırmada kullanılan ölçeklere ait bilgiler aşağıda verilmektedir. 
Akpulat, A. N., Polat Üzümcü, T., \& Karacan, E. (2016). Turizm işletmelerinde çalışanların yaşadıkları iş stresi ile örgütsel bağlllıkları ilişkisi, Çeşme ve Kartepe Örneği. Journal of Human Sciences, 13(3), 5136-5149. doi:10.14687/jhs.v13i3.4192

\section{- İş̧ Stresi Ölçeği}

Araştırma konusu olan iş stresinin ölçülmesi amacıyla, House ve Rizzo (1972)'nun geliştirdiği iş stresi ölçeği kullanılmıştır. Ölçek çalışanın iş yerinde yaşadığı stresle ilişkili olan psikolojik ve psikosomotik semptomlanı ölçmektedir. Ölçekte yedi madde yer almaktadır ve tek boyutludur. Her bir ifade likert tipi beşli dereceleme ölçeği üzerinden değerlendirilmektedir (1=Kesinlikle katılmıyorum-5=Kesinlikle katulıyorum). Araştırmada kullanılan ölçeğin Cronbach's Alpha değeri 0,81 'dir.

\section{- Örgütsel Bağlllık Ölçeği}

Örgütsel bağlllı̆̆ ölçmek için Husalid ve Day’in örgütsel bağll11k ölçeği kullanılmıştır. Husalid ve Day’in örgütsel bağllık değişkeninin ölçülmesi için kullanılan kısaltılmış 9 maddelik ölçek ise daha önce hazırlanmış olan 15 maddelik orijinal ilk ölçekle büyük ölçüde tutarlıdır (Huselid ve Day, 1991). Her bir ifade likert tipi beşli dereceleme ölçeği üzerinden değerlendirilmektedir. Araşturmada kullanılan ölçeğin Cronbach's Alpha değeri 0,88'dir.

\subsection{Veri Analizi}

Araştırma sonucunda elde edilen veriler araştırma amacı kapsamında bilgisayar programı ile analiz edilmiştir. Çalışmada demografik özellikleri ortaya çıkarmak amacı ile frekans ve yüzde dağılımları incelenmiş, hipotezleri test etmek amacıyla t-testi ve pearson korelasyon analizi kullanılmıştır.

Tablo 2: Turizm Çalışanlarının Çalıştıkları Turistik Destinasyona Göre İş Stresi Ölçeğinden ve Örgütsel Bağlılık Ölçeğinden Aldıkları Puanların Aritmetik Ortalama, Standart Sapma ve t-testi Değerleri

\begin{tabular}{|c|c|c|c|c|c|c|c|}
\hline Ölçekler & Grup Türü & $\mathbf{N}$ & $\bar{x}$ & Ss & Sd & $\mathbf{T}$ & $\mathrm{p}$ \\
\hline \multirow{3}{*}{ İş Stresi } & Çeşme & 185 & 19,55 & 5,72 & \multirow[t]{3}{*}{322} & \multirow[t]{3}{*}{1,74} & \multirow[t]{3}{*}{,082 } \\
\hline & Kartepe & 139 & 18,39 & 6,71 & & & \\
\hline & Toplam & 324 & 19,05 & 5,94 & & & \\
\hline \multirow[t]{3}{*}{ Örgütsel Bağlılık } & Çeşme & 185 & 32,11 & 7,72 & \multirow[t]{3}{*}{322} & \multirow[t]{3}{*}{3,18} & \multirow[t]{3}{*}{, $002 * *$} \\
\hline & Kartepe & 139 & 29,27 & 8,27 & & & \\
\hline & Toplam & 324 & 30,8 & 8,07 & & & \\
\hline
\end{tabular}

$\mathrm{P}<0,005$

Çeşme ve Kartepe'de çalışan turizm işletmeleri personeli, çalıştıkları destinasyonlara göre değerlendirildiğinde, iş stresi ölçeğinde anlamlı farklılaşmanın olmadığı görülmektedir. Bu sonuca göre H1 kabul edilmemiştir. Çalışan personelin çalıştıkları yere göre değerlendirildiğinde ise, örgütsel bağlılık ölçeğinde anlamlı bir farklılaşmanın olduğu görülmektedir. Bu sonuca göre $\mathrm{H} 2$ kabul edilmiştir. Örgütsel bağlılık ölçeğine verilen cevaplanı Çeşme (yaz turizmi), Kartepe (kış turizmi) ayrımına göre karşılaştırdığımızda, Çeşme destinasyonunda çalışan personelin örgütsel bağglı̆ı̆ının daha yüksek olduğu anlaşılmaktadır.

Tablo 3: Turizm Çalışanlarının İş Doyum Ölçeği ve Örgütsel Bağlılık Puanlarının Korelasyon Değerleri

\begin{tabular}{|l|l|l|l|l|l|}
\hline & N & Mean & Ss & R & Sig (2-tail) \\
\hline$\dot{I ̇ S ̧}_{\text {Stresi }}$ & 324 & 19,05 & 5,94 & -142 & \multirow{2}{*}{$010^{*}$} \\
\hline Örgütsel Bağll11k & 324 & 30,08 & 8,07 & & \\
\hline
\end{tabular}

$\mathrm{P}<0,005$

Turizm çalışanlarının iş stresi ve örgütsel bağlılığı puanları arasında anlamlı bir ilişkinin var olup olmadığını test etmek amaciyla Pearson Korelasyon Katsayısı hesaplanmıştır. Tablo 3 incelendiğinde, turizm işletmeleri personelinin iş stresi ile örgütsel bağllliğı arasında düşük düzeyde negatif ve anlamlı bir ilişki olduğu görülmektedir $(r=-142, p<5)$. Bu sonuçlara göre H3 kabul edilmiştir. 
Akpulat, A. N., Polat Üzümcü, T., \& Karacan, E. (2016). Turizm işletmelerinde çalışanların yaşadıkları iş stresi ile örgütsel bağlllıkları ilişkisi, Çeşme ve Kartepe Örneği. Journal of Human Sciences, 13(3), 5136-5149. doi:10.14687/ihs.v13i3.4192

\subsection{Bulgular}

Araştırmaya katılan turizm işletmeleri çalışanlarının sosyo- demografik özellikleri ile bulgular Tablo 1'de verilmiştir. Ankete katılanların \%57,1'inin Çeşme'de, \%42,9'unun ise Kartepe'de çalıştıkları görülmektedir. Her iki destinasyonun turizm çalışanlarının demografik özelliklerine bakıldığında, çalışanların \% 32,4'ü kadın, \%67,3’ü erkek, \% 59,3’ü bekâr, \% 40,7'si ise evli olup, Katılımcıların yaş aralığına göre dağılımları incelendiğinde; \% 83,3’ünün 39-19 yaş arasında, \%14'2'sinin 60-40 yaş arasında, \%8'inin 18 yaş ve altı olduğu anlaşılmaktadır. Çalışanların; \%32,7'sinin lise, \%29'unun lisans/lisansüstü, \%18,8'inin ilköğretim, \%18,5'inin önlisans mezunu olduğu görülmektedir. Anket sonuçlarından, bu iki turizm destinasyonu çalışanlarının; çoğunluğunun genç bekar erkeklerden oluştuğunu söylemek mümkündür.

\section{Tablo 1: Araştırmaya Katılan Turizm İşletmeleri Personelinin Demografik Özellikleri}

\begin{tabular}{|l|l|l|l|l|l|}
\hline Destinasyon & $\mathbf{n}$ & $\mathbf{0}$ & Cinsiyet & $\mathbf{n}$ & $\mathbf{\%}$ \\
\hline Çeşme & 185 & 57,1 & Kadın & 106 & 32,4 \\
\hline Kartepe & 139 & 42,9 & Erkek & 218 & 67,3 \\
\hline & & & & & \\
\hline Medeni Durum & $\mathbf{n}$ & $\mathbf{0}$ & Ĕ̈itim & $\mathbf{n}$ & $\mathbf{\%}$ \\
\hline Evli & 132 & 40,7 & İlköğretim & 61 & 18,8 \\
\hline Bekar & 192 & 59,3 & Lise & 106 & 32,7 \\
\hline & & & Önlisans & 60 & 18,5 \\
\hline & & & & & \\
\hline Çalı̧ma Alanları & $\mathbf{n}$ & $\mathbf{0}$ & Yaş1 & $\mathbf{n}$ & $\mathbf{\%}$ \\
\hline Konaklama & 217 & 67 & $39-19$ & 270 & 83,3 \\
\hline Yiyecek-İçecek & 88 & 27,2 & $60-40$ & 46 & 14,2 \\
\hline Seyahat & 19 & 5,9 & 18 ve alt1 & 13 & 8 \\
\hline & & & & & \\
\hline Günlük Çalısma Saati & $\mathbf{n}$ & $\mathbf{0}$ & Haftalık Çalışma Günü & $\mathbf{n}$ & $\mathbf{\%}$ \\
\hline 1-7 saat & 28 & 8,6 & 6 gün & 284 & 87,7 \\
\hline 8-12 saat & 284 & 87,7 & 7 gün & 12 & 3,7 \\
\hline 13 ve üstü & 12 & 3,7 & 5 gün ve altı & 28 & 8,6 \\
\hline
\end{tabular}

Katılımcıların günlük çalışma saatine göre dağılımında; \%87,7'sinin 8-12 saat arası, \%8,6'sının 1-7 saat arası, \%3,7'sinin 13 saat ve üzerinde çalıştığı, haftalık çalışma gününde ise, \% 87,7'si haftanın altı günü, \%3,7’sinin haftanın yedi günü çalıştı̆̆ı ve 5 gün altında çalışan sayısının da \% $\%, 6$ olduğu tespit edilmiştir. Araştırma bulgularına göre, turizm çalışanlarının büyük bir kısmının konaklama işletmelerinde çalışmakta olduğu, yönetici olmadıkları, kıdemsiz (1-9 y1l) oldukları ve çok büyük bir kısmının da haftanın altı günü çalıştığı ve uzun çalışma saatlerine tabi olduğu görülmektedir.

\section{TARTIŞMA}

Özkalp ve Kırel'e (1996)göre, "is stresörleri çesittl şekillerde ortaya çıkar ve işyerindeki herhangi bir şey

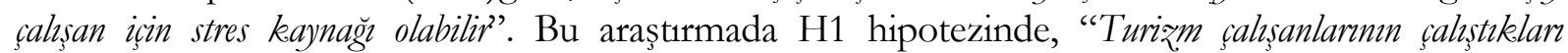
destinasyona göre (Çeşme ve Kartepe) is stresi açısından anlamlı bir farklillk vardır" ifadesi yer almaktadır. Elde edilen bulgulara göre turizm işletmeleri personeli çalıştıkları destinasyona göre (yaz ve kış turizmi) değerlendirildiğinde, iş stresi düzeylerinde anlamlı farklılaşmanın olmadığı görülmektedir. Bu sonuca göre, "turizm destinasyonlarnda sunulan turizm çşsitlerinde ve turizm ișletmeleri çalssanlarmon işlerinde farkhlikklar görülse de, bu durum is stresini arttırcı ya da azaltıcı bir etki yaratmamaktadı?". Turizm çalışanları, çalıştıkları destinasyona göre değerlendirildiğinde ise, örgütsel bağllıklanı açısından anlamlı bir farkl1l1k olduğu görülmektedir.

Örgütsel bağlllık, birçok faktörü etkileyebildiği gibi, çok sayıda faktörden de etkilenmektedir (Kaya, 2007: 10). Cinsiyet, yaş, medeni durum, eğitim seviyesi, örgütteki çalsşma süresi, işyükü, işin nitelikleri, sorumluluk ve denetim alanı, rol çatışması ve rol belirsizliği, monotonluk, stres, çalışma 
Akpulat, A. N., Polat Üzümcü, T., \& Karacan, E. (2016). Turizm işletmelerinde çalıșanların yaşadıkları iş stresi ile örgütsel bağlllıkları ilişkisi, Çeşme ve Kartepe Örneği. Journal of Human Sciences, 13(3), 5136-5149. doi:10.14687/jhs.v13i3.4192

koşulları, sahiplik durumu, faaliyet dönemi ve müşteri ile ilişkiler, yönetim kademeleri, yönetim tarzı, yetki devri, örgüt büyüklüğü, örgüt içi iletişim, ücret düzeyi, terfi ve ödül sistemi, emek yoğun üretim, işgören devir oranı, sosyal güvence ve sendikanın varllğı gibi faktörler örgütsel bağllilı̆ı etkilemektedir (Güçlü, 2006). Araştırmada turizm personelinin çalıştıkları destinasyon türüne göre örgütsel bağlılıklarında farklılık olup olmadığı araştırılmış, "H2= Turizm çalışanlarının çalıştıkları destinasyona göre (Çeşme ve Kartepe) örgütsel bağlllık açısından anlamlı bir farkllılı vardır" hipotezi kabul edilmiştir. Bu sonuca göre, yaz turizmi merkezi olan Çeşme'de, örgütsel bağlılığın, kış turizmi merkezi olan Kartepe'den daha yüksek olduğu sonucuna varılmıştır. Bu sonucu, ülkemizde yaz turizmine göre kış turizminin daha geç keşfedilmiş olması ve kış turizminin daha yeni turizm türü olmasına bağlanabilir. Ülkemizde turizm, klasik turizm olarak ifade edilen deniz, kum ve güneşe dayanan, yaz aylarında yoğunluğun yaşandığı deniz turizmi ile başlamış olup, Çeşme ilçesi ülkemizde yaz turizminin ilk gelişmeye başladığı yerlerdendir. Bu nedenle Çeşme destinasyonunda yer alan turizm işletmelerinin, Güçlü’nün saymış olduğu örgütsel bağlllı̆̆ arttıran unsurlar açısından daha iyi seviyede olduğu düşünülebilir. Bu nedenle Çeşme ilçesinde çalışan, turizm işletmeleri personelinin örgütsel bağlllı̆̆ının daha yüksek olduğunu söylemek mümkündür.

Turizm çalışanlarının iş stresi ve örgütsel bağlllı̆̆ arasında düşük düzeyde negatif yönde anlamlı bir ilişki olduğu bulunmuştur. Diğer bir ifade ile araşturmaya katılan Çeşme ve Kartepe'de çalışan personelin tamamının iş stresleri arttıkça, örgütsel bağlllıklarında azalma olduğu anlaşılmaktadır. Bu sonuçlar doğrultusunda, çalışan personelin iş stresi seviyesinin azaltılarak, örgütsel bağlılıklarının arttırılması gerektiği söylenebilir.

\section{SONUÇ}

Turizm, ülkelerin döviz rezervlerini artıran, işsizlik oranlarını düşüren ve diğer sektörlerin gelişimini sağlayan lokomotif bir sektör konumundadır (Tutar vd., 2013). Bir hizmet sektörü olan turizm sektörünün başarısı ise, hizmet kalitesinin sürekliliği ve müşteri memnuniyetinin sağlanması ile mümkündür (Üzümcü, 2015). Bu başarıy gerçekleştirmek ise, ancak turizm personeli ile sağlanabileceğinden, turizm işletmeleri yönetimlerinin, üzerinde durması gereken en önemli hususlardan birisi turizm çalışanlarının işlerine ve işletmelerine duydukları bağlliktır. Bu örgütsel bağlılığın oluşturulmasında, çalışanların iş streslerinin azaltılması önemli bir faktördür. Bu bağlamda bu çalş̧ma, emek yoğun bir sektör olan turizm sektörü için vazgeçilmez öneme sahip turizm çalışanlarının iş stresleri ve örgütsel bağlılıklanı ilişkisinin incelenmesi amacıyla yapılmıştır. Araştırma, farklı turistik çekiciliklere sahip olan Çeşme ve Kartepe turizm destinasyonlarında faaliyet gösteren; konaklama işletmeleri, seyahat işletmeleri ve yiyecek-içecek işletmeleri çalışanları üzerinde yapılmıştır.

Yapılan araştırmada turizm işletmeleri çalışanları, demografik özellikleri bakımından irdelendiğinde, Çeşme ve Kartepe destinasyonları turizm işletmeleri çalışanlarının çoğunluğunun genç $(\% 83,3)$, bekar $(\% 59,3)$,erkek $(\% 67,3)$, lise ve üstü eğitime $(\% 61,7)$ sahiptir. Ankete katılan turizm işletmeleri personelinin büyük bir kısmının haftanın 6 günü $(\% 87,7)$ ve günde 8 saatin üzerinde çalıştı̆ı (\%91) görülmektedir. Araştırma bulgularına göre, turizm çalışanlarının büyük bir kısmının iş stresine neden olabilecek ve örgütsel bağlıllı̆ı azaltabilecek çalışma koşullarına maruz kaldıkları anlaşılmaktadır.

Analiz sonuçlanına göre; Çeşme ve Kartepe'de çalışan personel destinasyon bazında değerlendirildiğinde, iş stresi ölçeğinde anlamlı bir farklılık olmadığı, ancak örgütsel bağllıkları açısından anlamlı bir farklılık olduğu görülmektedir. Buna göre, bu turizm destinasyonlarında sunulan turizm çeşitlerinde ve çalışanların işlerinde farkllikklar görülse de, bu durum iş stresini arttırıcı ya da azaltıc bir etki yaratmamaktadır. Bu sonuca göre, yaz turizmi merkezi olan Çeşme'de, örgütsel bağlılığın, kış turizmi merkezi olan Kartepe'den daha yüksek olduğu sonucuna varılmıştır. Bunun nedenini, ülkemizde kış turizminin, yaz turizmine göre daha yeni bir turizm türü olması ve kış turizm destinasyonlarına olan talebin yeni oluşmaya başlamasına bağlamak mümkündür. 
Akpulat, A. N., Polat Üzümcü, T., \& Karacan, E. (2016). Turizm işletmelerinde çalıșanların yaşadıkları iş stresi ile örgütsel bağlllıkları ilişkisi, Çeşme ve Kartepe Örneği. Journal of Human Sciences, 13(3), 5136-5149. doi:10.14687/ihs.v13i3.4192

Ülkemizde turizm, deniz, kum ve güneşe dayanan, yaz aylarında yoğunluğun yaşandı̆̆ deniz turizmi ile gelişmiştir. Özellikle Çeşme 1960’lı yllar itibariyle yaz turizmi merkezi olmaya başlamıştır. Oysa Kartepe destinasyonu, 2006 yll itibariyle kış turizmi merkezi olarak hizmet vermeye başlamıştır. Bu bağlamda Çeşme'de deneyimli turizm işletmeciliği yapılırken, Kartepe'de yeni yeni turizm işletmeciliŭgi gelişmektedir. Örgütsel bağlllık, pek çok faktörden (yaş, cinsiyet, eğitim, çalışma süresi, iş yükü, çalışma koşulları, işin nitelikleri, sorumluluk ve denetim alanı, rol çatışması ve rol belirsizliği, monotonluk, sahiplik durumu, yönetim tarzı, yetki devri, örgüt büyüklügü, ücret düzeyi, iş stresi vb.) etkilenmektedir. Bu nedenle İzmir ili Çeşme destinasyonunda yer alan turizm işletmelerinin örgütsel bağlllı̆̆ı arttıran unsurlar açısından daha iyi seviyede olduğu ve Çeşme ilçesinde çalışan turizm işletmeleri personelinin örgütsel bağllliğının daha yüksek olduğunu söylemek olasıdır. Turizm çalışanlarının iş stresi ve örgütsel bağlılığı arasında ise, düşük düzeyde negatif yönde anlamlı bir ilişki olduğu bulunmuştur. Bunun anlamı, araştırmaya katılan Çeşme ve Kartepe'de çalsşan turizm işletmeleri personelinin, iş stresleri arttıkça örgütsel bağlllıklarında azalma olduğudur. Buna göre, turizm işletmelerinde çalışan personelin iş stresi seviyesinin azaltılarak, örgütsel bağlllıklarının arttırılması gerektiğini söylemek mümkündür.

Sonuç olarak; iş stresi bir sorun olarak değerlendirilebileceği gibi bir sorunun belirtisi olarak da değerlendirilmelidir. Bu sebeple, iş stresini doğal bir sorun olarak görmek yerine, bir iyileşme firsatı olarak görmek ve (Akova ve Işık, 2008) turizm işletmelerinin iş stresini, örgütsel bağlllı̆̆1 artırmada bir araç olarak kabul etmeleri gerekmektedir. Daha net bir ifadeyle; iş stresi azalan ve örgütsel bağlllı̆̆ artan çalışanların, motivasyonları ve performansı yükselerek, hizmet kalitesi ve müşteri memnuniyeti artacak, dolayısıyla destinasyon ya da işletme ulusal/küresel turizm pazarında söz sahibi olabilecektir.

$\mathrm{Bu}$ araştırma, yaz ve kış turizm destinasyonlarında çalışan turizm çalışanlarına yönelik olup, farklı destinasyonlarda hizmet sunan turizm işletmelerinde yapılacak araştırmalara kaynak oluşturabilecektir. İşs stresi ve örgütsel bağlllk ilişkisinin turizm işletmelerinde; verimlilik, hizmet kalitesi ve müşteri memnuniyetinin etkileri gibi faktörler ile ilgili yeni çalışmalar yapılması, turizm yazınına katkı sağlayacaktır. Özellikle turizm sektöründe iş stresi konusunda ki çalışmaların azlığı ve iş stresinin çalışan motivasyonu, performansı, örgütsel bağlllı̆̆1 vb. üzerindeki etkisi sebebiyle, daha büyük ve farklı destinasyonlarda, farklı çalışmalar yapılması yararlı olabilecektir.

\section{KAYNAKÇA}

Akgündüz Y. \&Güzel T. (2014). Örgütsel Adalet İle Örgütsel Bağlllık Arasındaki İlişkide Örgütsel Güvenin Aracilık Etkisi, Anadolu Üniversitesi Sosyal Bilimler Dergisi, 14(3), 1-17.

Akova O., Işık K. (2008). Otel İşletmelerinde Stres Yönetimi: İstanbul'daki Beş Yıldızlı Otel İşletmelerinde Bir Araştırma, Kocaeli Üniversitesi Sosyal Bilimler Enstituisü Dergisi, 15(1), 17-44.

Altaş S.S., Çekmecelioğlu Gündüz H. (2015). Örgütsel Adalet Algısının İş Tatmini, Örgütsel Bağlllık ve İş Performansı Üzerindeki Etkileri: Okul Öncesi Öğretmenleri Üzerinde Bir Araştırma. Atatürk Üniversitesi İktisadi ve İdari Bilimler Dergisi, 29 (3),421-439.

Aslan Z. \& Cengiz E.(2015). Akademisyenlerin İş Stresi ile İş Motivasyonu İlişkisi,Gümüşhane Üniversitesi Sosyal Bilimler Elektronik Dergisi, Say1 12,26-43.

Aydın Ş. (2004). Örgütsel Stres Yönetimi. Dokuг Eylül Üniversitesi Sosyal Bilimler Enstitüsü Dergisi, 6(3), 49-74.

Balcı, A. (2002). Örgütsel Gelişme Kavram ve Uygulama, 3. Baskı, Pegem Yayıncllk, Ankara.

Candan B. ve Çekmecelioğlu Gündüz H. (2009). İçsel Pazarlama Faaliyetlerinin Örgütsel Bağlllık Unsurları Acısından Değerlendirilmesi: Bir Araştırma, Yönetim, 20 (63), 41-58. 
Akpulat, A. N., Polat Üzümcü, T., \& Karacan, E. (2016). Turizm işletmelerinde çalıșanların yaşadıkları iş stresi ile örgütsel bağlllıkları ilişkisi, Çeşme ve Kartepe Örneği. Journal of Human Sciences, 13(3), 5136-5149. doi:10.14687/jhs.v13i3.4192

Çelik M. ve Turunç Ö (2009). Aile-İş Çatışması, İş Stresi ve Örgütsel Sadakatin İş Performansına Etkisi: Savunma Sektöründe Ampirik Bir Çalışma, Kara Harp Okulu Savunma Bilimleri Dergisi, 217-245. www.kho.edu.tr/akademik/enstitu/savben dergi/82/makale10.pdf

Çınar O. (2010). Eğitim ve Sağlık Alanı Çalışanlarının İs Stresi Düzeyleri.Elektronike Sosyal Bilimler Dergisi, 9(33), 101-121.ISSN:1304-0278,www.esosder.org.

Demirel Y. (2009).Örgütsel Bağlılık ve Üretkenlik Karşıtı Davranışlar Arasındaki Illişkiye Kavramsal Yaklaşım, Istanbul Ticaret Üniversitesi Sosyal Bilimler Dergisi, 8 (15), 115-132.

Efeoğlu E. ve Özgen H. (2007). İş-Aile Yaşam Çatısmasının İş Stresi, İş Doyumu ve Örgütsel Bağll1ık Üzerindeki Etkileri: İlaç Sektöründe Bir Araştırma. Ç.Ü. Sosyal Bilimler Enstitüsü Dergisi, 16 (2),237-254.

Eren E. (2004). Örgütsel Davranış ve Yönetim Psikolojisi, Genişletilmiş 8. Bas1, Beta Basım A.Ş., İstanbul.

Genç, N. (2005). Yönetim ve Organizasyon Çağdaş Sistemler ve Yaklaşımlar, Seçkin Yaymncllk, 2.Bask1, Ankara.

Güçlü, H. (2006), Turizm Sektöründe Durumsal Faktörlerin Örgütsel Bağlllık Üzerindeki Etkisi, (Yayımlanmamış Doktora Tezi), Anadolu Üniversitesi, Sosyal Bilimler Enstitüsü, Eskişehir.

Gündoğan, T. (2009). Örgütsel Bağlllık: Türkiye Cumhuriyeti Merkez Bankası Uygulamas1, Uzmanllk Yeterlilik Tezi, Türkiye Cumburiyeti Merkez. Bankası Insan Kaynaklar Genel Müdürlï̈̆̈̈, Ankara.

Güney, S.(2011). Örgütsel Davranış, Nobel Yayın Dağıtım, Ankara, 2011.

Huselid, M.A, Day, N. E., (1991). Organizational Commitment Job Involvement and Turnover: A Sustantive and Methodological Analysis, Journal of Applied Psychology, 76 (3), Amerikan Psychological Association Inc.,381.

Kavacık M., Baltacı F. ve Yıldız A. (2013).Konaklama İşletmelerinde Örgütsel Çatışma ve Örgütsel Bağlılık Arasındaki İlişkiyi Belirlemeye Yönelik Bir Araştırma. Uluslararası Alanya İsletme Fakültesi Dergisi,5 (3), 73-85.

Kaya, O. (2007), Örgütsel Bağlllik: Emniyet Genel Müdürlüğ̈ Merkez Biriminde Bir Uygulama, (Yayımlanmamıs Yüksek Lisans Tezi), Gaž Üniversitesi Eğitim Bilimleri Enstitüsü, Ankara.

Korkmaz O. ve Erdoğan E. (2014).İş Yaşam Dengesinin Örgütsel Bağllilk ve Çalışan Memnuniyetine Etkisi,Ege Akademik Bakıs, 14 (4),541-557.

Meyer J. P., Stanley D.J, Herscovitch L. and Topolnytsky L. (2002). Affective, Continuance, and Normative Commitment to the Organization: A Meta-analysis of Antecedents, Correlates, and Consequences,Journal of Vocational Behavior61, 20-52. doi:10.1006/jvbe.2001.1842

Refik B. (2000). Örgütsel Bağllik.Nobel Yaym Dağıtım, Ankara.

R.J. ve J.R. Rizzo (1972). Role Conflict and Ambiguity as Critical Variables in Model of Organizational Behavior, Organizational Behavior and Human Performance, 7, 467-505.

Özkalp E. ve Kırel Ç. (1996). Anadolu Üniversitesi Eğitim, Sağlık, ve Bilimsel Araştırma Çalışmaları Vakfi Yayınları No.11, ETAM A.Ş. Matbaa Tesisleri, Eskişehir.

Sabuncuoğlu Z. ve Tüz M. (2003.) Örgütsel Psikoloji, Gözden Geçirilmiş 4. Baskı, Furkan Ofset, Bursa.

Selye H. (1976). Forty Years Of Stress Research: Principal Remaining Problems and Misconceptions. CMA Journal, 3 (115), 53-53.

Turunç Ö. (2015). İş Stresi -Kaytarma İlişkisinde Liderin Rolü, Turizm Sektöründe Bir Araştırma, Uluslararast İktisadi ve İdari Bilimler Dergisi-DEAS, 1(2), 142-159.

Üzümcü T.P. (2015). Otel Yöneticilerinin Turizm Eğitimine Yönelik Algilar1: Kocaeli İli Otel Yöneticileri Üzerinde Bir Araştırma, Kocaeli Üniversitesi Sosyal Bilimler Dergisi (KOSBED), 30, 123-150.

Yıldırım, A. ve Şimşek, H. (2004). Sosyal Bilimlerde Nitel Araştırma Yöntemleri. Seçkin Yayıncılık: Ankara. 
Akpulat, A. N., Polat Üzümcü, T., \& Karacan, E. (2016). Turizm işletmelerinde çalıșanların yașadıkları iş stresi ile örgütsel bağlllıkları ilişkisi, Çeşme ve Kartepe Örneği. Journal of Human Sciences, 13(3), 5136-5149. doi:10.14687/jhs.v13i3.4192

\section{Extended English Abstract}

Although job stress, which affects the majority of employees in the organization, has positive effects on employees to a certain level, it may cause undesired attitudes and discomfort beyond that level (Ironson, 1992:35; as cited in: Turunç, 2015). Additionally, the presence of an employee with high stress load in the working environment may negatively affect the safety of both the employee in question and other employees (Genç, 2005:263). The predecessor and sometimes the successor of many individual and organizational factors, job stress is an important factor required to be managed due to its outcomes.

Organizational commitment is the psychological commitment of individuals for the organization (O'Reilley, 1989; as cited in: Candan and Çekmecelioğlu, 2009) and employees' and managers' act of remaining loyal to organizational values. Thus, individuals comply with both their own and organization's principles and values. Until recent years, the organizational commitment theory and research have primarily focused on outcomes for employers, whereas the majority of studies today examine relations between employees and commitment which include stress and jobfamily conflicts (Meyer et al., 2002: 22). Employees with high organizational commitment have a low level of concern about the future and intention to quit and since they internalize objectives and goals of the organization, their job stress and slowdown strike remain at low levels (Wasti, 2005: 296; as cited in: Kavacık, Baltacı and Yıldız, 2013: 76).

This study investigates the relation between job stress level and organizational commitment of employees in tourism establishments (hotel, restaurant, travel agency, etc.). The present study was conducted in order to examine job stress and organizational commitment of employees in tourism establishments in Çeşme and Kartepe destinations which have different touristic attractions. The study survey was administered to a total of 351 employees working at tourism establishments in Çeşme, a summer tourism destination in the province of İzmir and Kartepe, a winter tourism destination in the province of Kocaeli. 329 were evaluated whilst 22 surveys were excluded from the evaluation due to reasons such as missing answers or choosing the same option for all questions.

The scale developed by House and Rizzo (1972) was used in order to measure job stress which is the focus point of this study. The scale measures psychological and psychosomatic symptoms associated with stress experienced by employees in the workplace. The scale consists of seven items and is one-dimensional. Each item is evaluated on a five-point Likert scale (1=Strongly disagree, $5=$ Strongly agree). The job stress scale used in the study has a Cronbach's Alpha coefficient of 0.81 . The scale developed by Huselid and Day was used to measure organizational commitment. The 9item summarized scale developed by Huselid and Day to measure the organizational commitment variable is largely with the original scale consisting of 15 items (Huselid and Day, 1991). Each item is evaluated on a five-point Likert scale. The organizational commitment scale used in the study has a Cronbach's Alpha coefficient of 0.88. The research hypotheses developed in order to examine job stress and organizational commitment of employees working in tourism destinations with different characteristics are as follows:

$\mathrm{H} 1=$ There is a significant difference in terms of job stress between tourism employees depending on the destination where they work (Çeşme and Kartepe).

$\mathrm{H} 2=$ There is a significant difference in terms of organizational commitment between tourism employees depending on the destination where they work (Çeşme and Kartepe).

$\mathrm{H} 3=$ There is a significant correlation between job stress and organizational commitment of tourism employees.

The data obtained as a result of the study were analyzed with computer software for the purpose of the study. Frequency and percentage distributions were examined in order to reveal demographic characteristics and t-test and pearson correlation analysis were used to test 
Akpulat, A. N., Polat Üzümcü, T., \& Karacan, E. (2016). Turizm işletmelerinde çalıșanların yaşadıkları iş stresi ile örgütsel bağlllıkları ilişkisi, Çeşme ve Kartepe Örneği. Journal of Human Sciences, 13(3), 5136-5149. doi:10.14687/jhs.v13i3.4192

hypotheses. No significant difference in terms of job stress was found between employees working at tourism establishments in Çeşme and Kartepe depending on their destination. According to this result, H1 was not accepted. A significant difference was observed in the organizational commitment scale between employees depending on their destination. According to this result, $\mathrm{H} 2$ was accepted. Comparing answers given to the organizational commitment scale according to the distinction of Çeşme (summer tourism) and Kartepe (winter tourism), it was found that employees working in Çeşme had higher organizational commitment. A weak, negative and significant correlation was observed between job stress and organizational commitment of employees working at tourism establishments $(\mathrm{r}=-142, \mathrm{p}<5)$. According to these results, H3 was accepted.

According to Özkalp and Kırel (1996), "job stressors emerge in a variety of ways and anything in the workplace may be a source of stress for the employee." The first hypothesis of the study involves the statement of "There is a significant difference in terms of job stress between tourism employees depending on the destination where they work (Çeşme and Kartepe)." According to the findings obtained, no significant difference in terms of job stress was present between employees working at tourism establishments depending on their destination (summer and winter tourism). According to this result, "although there are differences in terms of services offered in tourism destinations and jobs of employees of tourism establishments, these do not increase or decrease job stress."

There was a significant difference in terms of organizational commitment between tourism employees depending on their destination. Organizational commitment affects many factors (Kaya, 2007: 10) and is affected by many factors as well such as age, gender, education, working time, workload, working conditions, the nature of the job, area of responsibility and control, role conflict and role ambiguity, monotony, ownership status, management style, delegation of authority, the size of the organization, salary level, job stress, etc. (Güçlü, 2006). The study investigated whether there was a difference in terms of organizational commitment between tourism employees depending on their destination and the hypothesis " $\mathrm{H} 2=$ There is a significant difference in terms of organizational commitment between tourism employees depending on the destination where they work (Çeşme and Kartepe)" was accepted. For this reason, it can be said that tourism establishments in Çeşme are in better shape in terms of factors enhancing organizational commitment and employees working at tourism establishments in the district of Çeşme have higher organizational commitment. This finding might be associated with the fact that winter tourism was discovered later than summer tourism in Turkey and winter tourism is a relatively new type of tourism.

A weak, negative and significant correlation was found between job stress and organizational commitment of tourism employees, which means that the increase in job stress of tourism employees participated in the study resulted in a decrease in their organizational commitment. It can be said according to this finding that it is necessary to decrease job stress levels and increase organizational commitment of employees working at tourism establishments.

In conclusion, although it is possible to consider job stress as a problem, it should also be considered as the symptom of a problem. For this reason, instead of seeing job stress as a natural problem, tourism establishments should consider job stress as an opportunity for improvement (Akova and Iş1k, 2008) and as a tool to enhance organizational commitment. To put it more explicitly, employees with decreased job stress and increased organizational commitment will have higher motivation and performance, the quality of service and customer satisfaction in tourism establishments will increase and thus, the destination or the establishment will have a corner in the tourism market on both national and international level. 